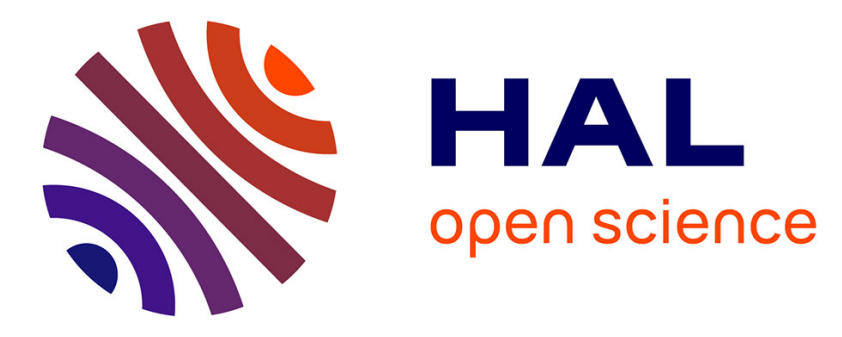

\title{
A brief status on condition monitoring and fault diagnosis in wind energy conversion systems
}

Yassine Amirat, Mohamed Benbouzid, Elie Al-Ahmar, Bachir Bensaker, Sylvie Turri

\section{- To cite this version:}

Yassine Amirat, Mohamed Benbouzid, Elie Al-Ahmar, Bachir Bensaker, Sylvie Turri. A brief status on condition monitoring and fault diagnosis in wind energy conversion systems. Renewable and Sustainable Energy Reviews, 2009, 3 (9), pp.2629-2636. 10.1016/j.rser.2009.06.031 . hal-00525370

\author{
HAL Id: hal-00525370 \\ https://hal.science/hal-00525370
}

Submitted on 12 Oct 2010

HAL is a multi-disciplinary open access archive for the deposit and dissemination of scientific research documents, whether they are published or not. The documents may come from teaching and research institutions in France or abroad, or from public or private research centers.
L'archive ouverte pluridisciplinaire HAL, est destinée au dépôt et à la diffusion de documents scientifiques de niveau recherche, publiés ou non, émanant des établissements d'enseignement et de recherche français ou étrangers, des laboratoires publics ou privés. 


\title{
A Brief Status on Condition Monitoring and Fault Diagnosis in Wind Energy Conversion Systems
}

\author{
Yassine Amirat, Mohamed El Hachemi Benbouzid, Elie Al-Ahmar, \\ Bachir Bensaker and Sylvie Turri
}

\begin{abstract}
There is a constant need for the reduction of operational and maintenance costs of Wind Energy Conversion Systems (WECS). The most efficient way of reducing these costs would be to continuously monitor the condition of these systems. This allows for early detection of the degeneration of the generator health, facilitating a proactive response, minimizing downtime, and maximizing productivity. Wind generators are also inaccessible since they are situated on extremely high towers, which are normally $20 \mathrm{~m}$ or more in height. There are also plans to increase the number of offshore sites increasing the need for a remote means of WECS monitoring that eliminates some of the difficulties faced due to accessibility problems. Therefore and due to the importance of condition monitoring and fault diagnosis in WECS (blades, drive trains, and generators); and keeping in mind the need for future research, this paper is intended as a brief status describing different type of faults, their generated signatures, and their diagnostic schemes.
\end{abstract}

Index Terms - Wind turbine, induction generator, drive train, condition monitoring, fault diagnosis.

Y. Amirat ${ }^{1}$, M.E.H. Benbouzid, E. Al-Ahmar ${ }^{2}$ and S. Turri are with the University of Brest, EA 4325 LBMS, Rue de Kergoat, CS 93837, 29238 Brest Cedex 03, France (email: m.benbouzid@ieee.org). ${ }^{1}$ Y. Amirat is also with the Electrical Engineering Department, University of Annaba, 23000 Annaba, Algeria. ${ }^{2}$ E. Al-Ahmar is also with the Faculty of Sciences and Computer Engineering, Holy Spirit University of Kaslik, BP 446, Jounieh, Lebanon.

B. Bensaker is with the University of Annaba, Electrical Engineering Department, 23000 Annaba, Algeria. 


\section{INTRODUCTION}

Wind energy conversion is the fastest-growing source of new electric generation in the world and it is expected to remain so for some time. At the end of 2003 the installed wind capacity stood at over $40000 \mathrm{MW}$, having doubled since 1999, and it could exceed $95000 \mathrm{MW}$ by the end of 2008 (Fig. 1). But the higher target is to achieve 12\% of the world's electricity from wind power by 2020. Harnessing wind energy for electric power generation is an area of research interest and at present, the emphasis is given to the cost-effective utilization of this energy resource for quality and reliable power supply. During the last two decades wind turbines have been developed in size from 20 $\mathrm{kW}$ to $2 \mathrm{MW}$, while even larger wind turbines are already being designed [1].

Autonomous online condition monitoring systems with integrated fault detection algorithms allow early warnings of mechanical and electrical faults to prevent major component failures.

Side effects on other components can be reduced significantly. Many faults can be detected while the defective component is still operational. Thus, necessary repair actions can be planned in time and need not to be taken immediately. This is important as WECS generators are inaccessible since they are situated on extremely high towers, which are normally $20 \mathrm{~m}$ or more in height (Fig. 2). It is also important especially for offshore plants, where bad weather conditions (storms, high tides, etc.) can prevent any repair actions for several weeks (Fig.2). Moreover, condition monitoring will also detect extreme external conditions, such as icing or water induced tower oscillations of offshore plants, and can trigger appropriate control actions to prevent damage of plants components. This way, overall maintenance costs and downtime of wind energy converters can be significantly reduced [2-6].

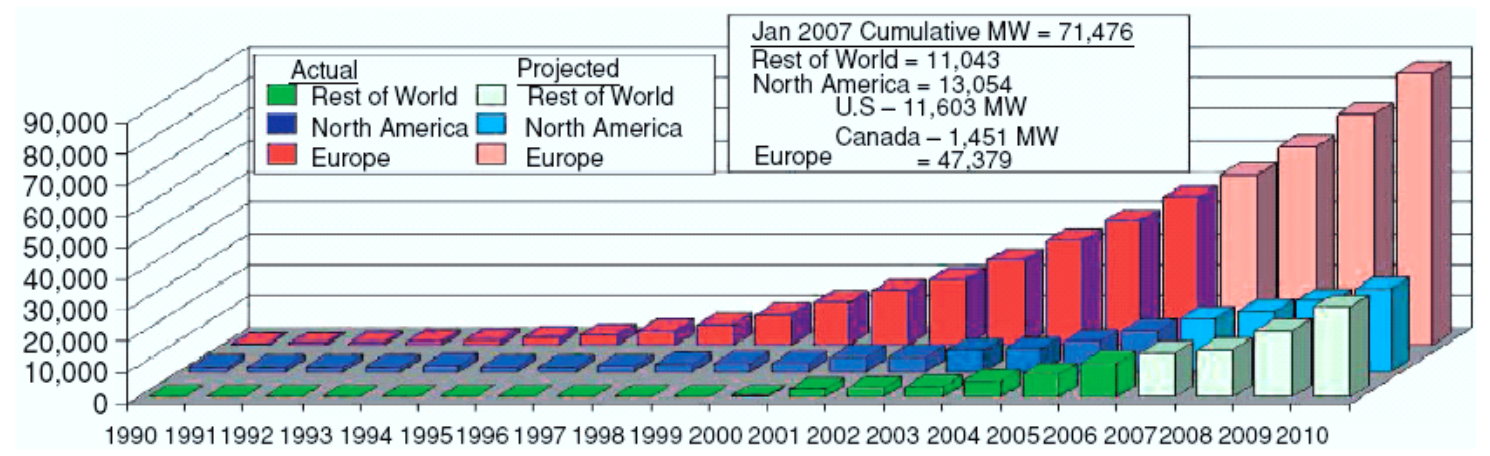

Fig. 1. Worldwide growth of wind energy installed capacity [1]. 

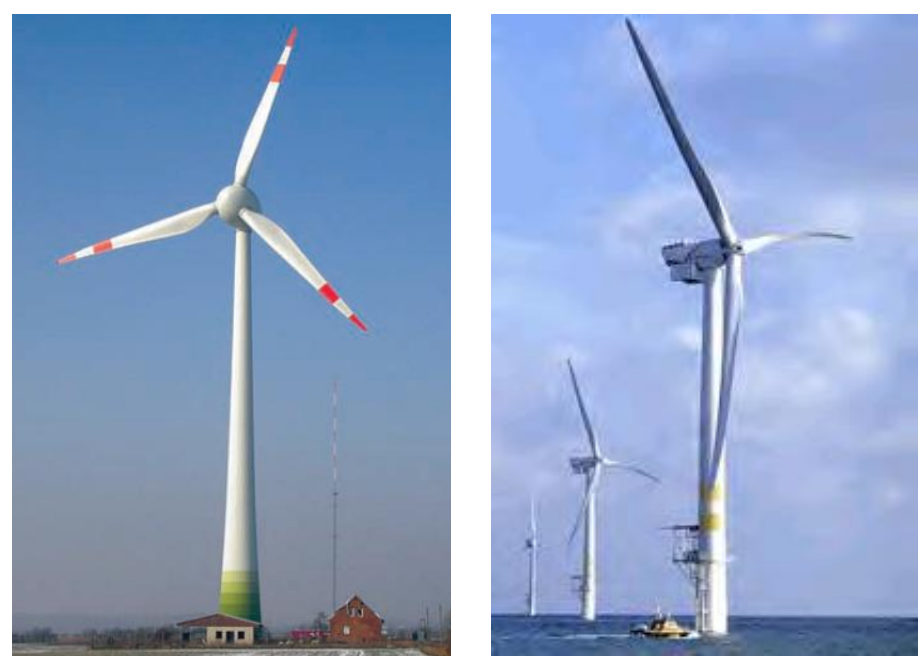

Fig. 2. Currently largest onshore wind turbine and offshore installations [7].

Therefore and due to the importance of condition monitoring and fault diagnosis in WECS (blades, drive trains, and generators); and keeping in mind the need for future research, this paper is intended as a brief status based on an exhaustive review of the state of the art, describing different type of faults, their generated signatures, and their diagnostic schemes. As the Doubly-Fed Induction Generator (DFIG) is one of the most used WECS configurations, the review will be mainly focused on it (Fig. 3).

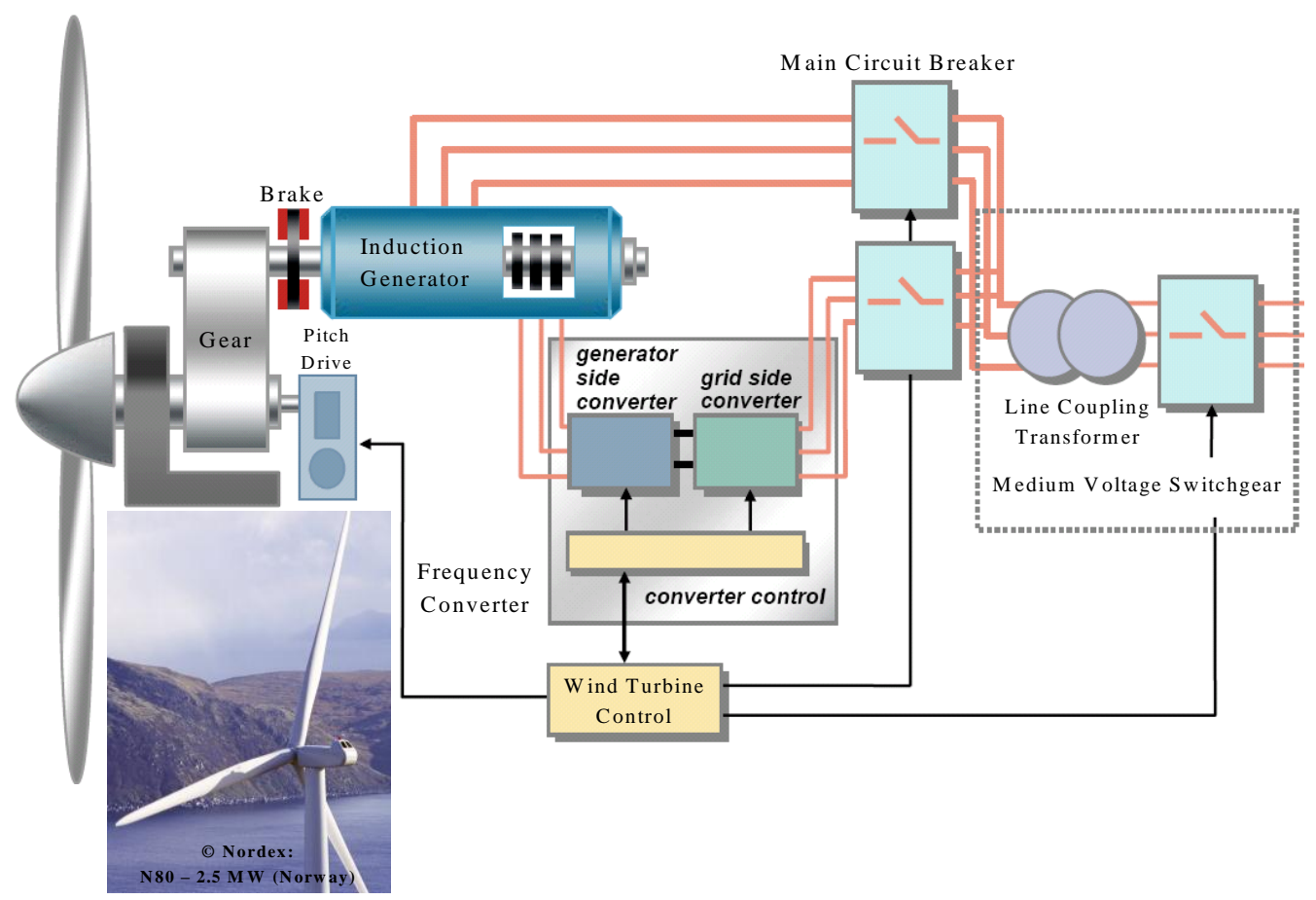

Fig. 3. Most used WECS configuration (with DFIG arrangement) [7]. 


\section{FAILURE MODE ANALYSIS}

Real wind turbine failure data quantitative analyses have shown important features of failure rate values and trends [8-11]. For illustration, Fig. 4 shows the main wind turbine components that are concerned by the above failure analyses.

In the first study concerning Swedish wind power plants [8-9], it has been shown that most failures were linked to the electric system followed by sensors, and blades/pitch components. This is clearly illustrated by Fig. 5 that shows failures number distribution for Swedish wind power plants that occurred between 2000 and 2004.

Another study, concerning Danish and German wind power plants [10], shows the same tendency. Indeed, principal contributors to the higher German failure rate are the electrical control or system subassemblies (grid or electrical system, yaw system and mechanical or pitch control system) rather than mechanical subassemblies such as the gearbox. Then Fig. 6 shows the failure rate in the two power plants during the period 1994-2004.

All the above analyses are consistent with the introduction of variable speed drive technology but are contrary to the received wisdom that gearboxes are a major cause of turbine failure [12].

For the above reasons, the proposed review will be focused on these types of failure.

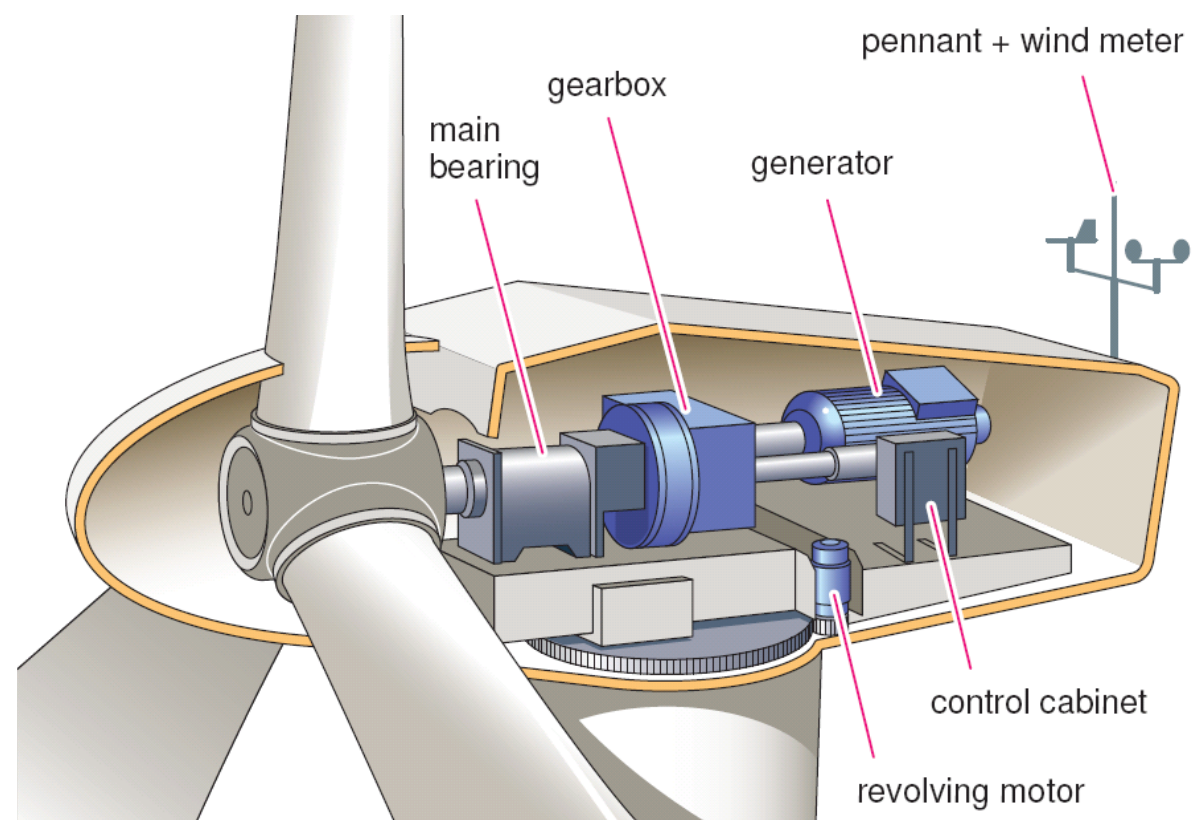

Fig. 4. Wind turbine nacelle cross-section. 


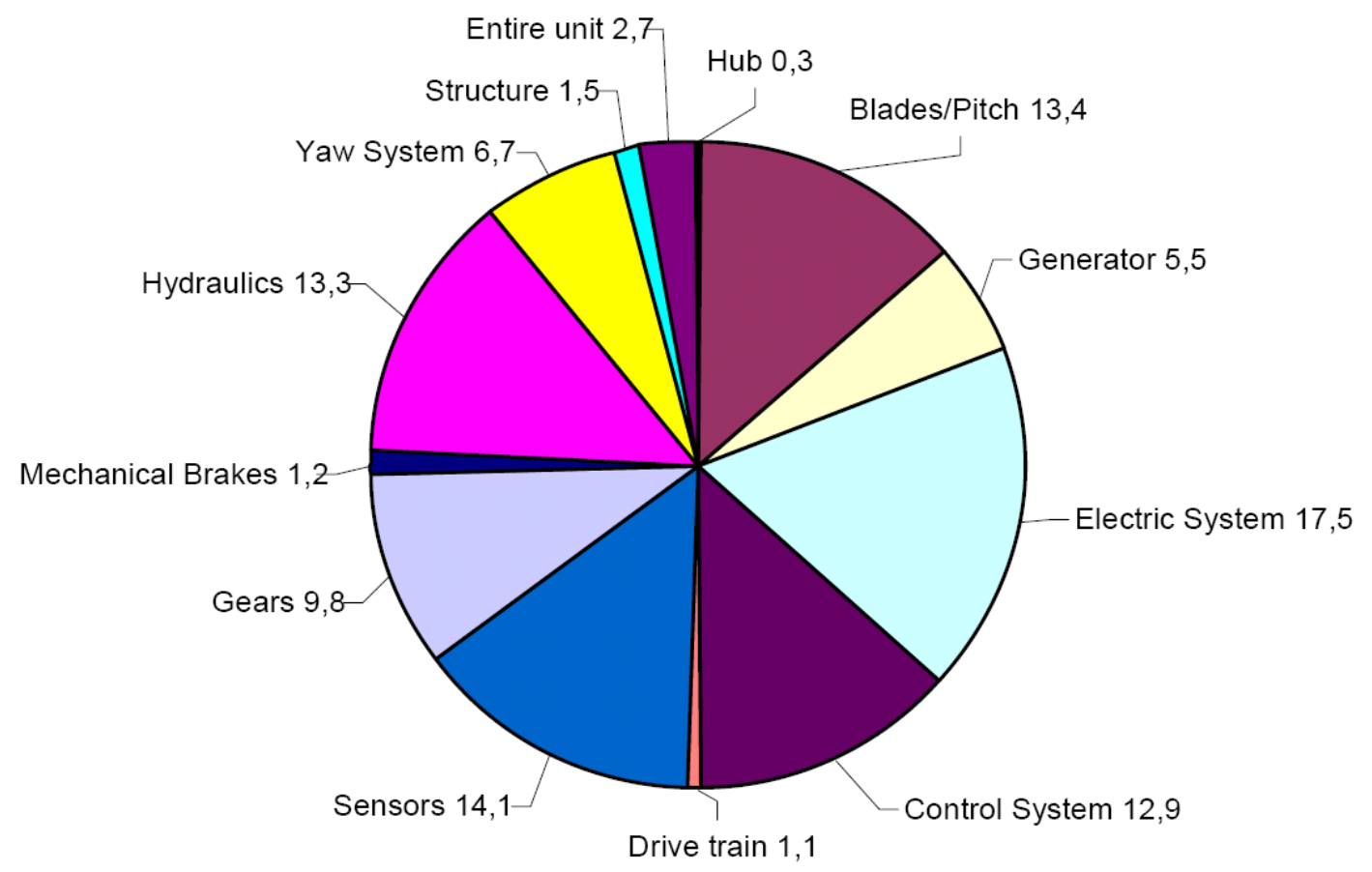

Fig. 5. Failures number distribution [\%] for Swedish wind power plants [8].

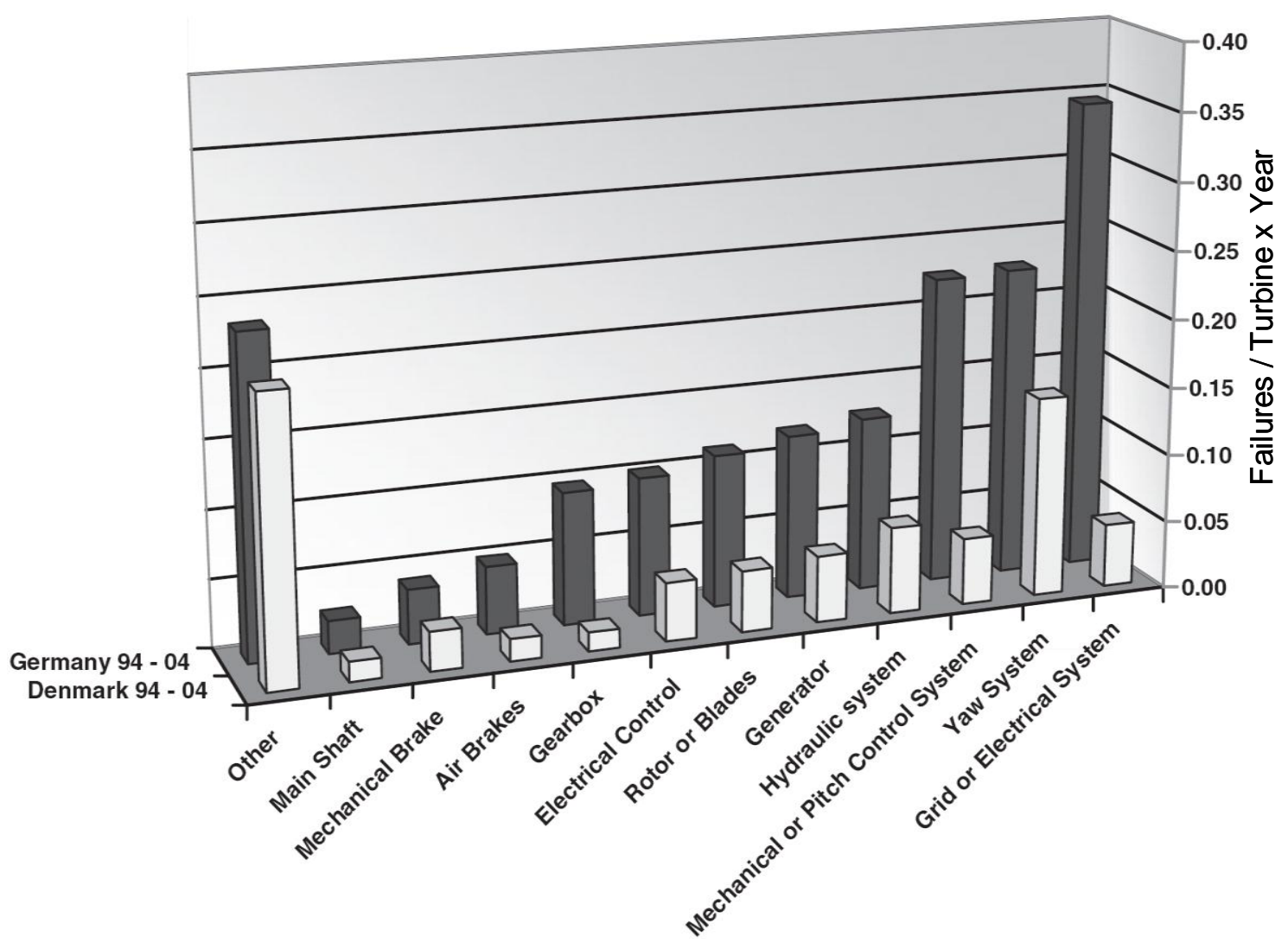

Fig. 6. Failure rates for Danish and German wind power plants [10]. 


\section{CONDITION MONITORING AND DIAGNOSIS}

It is well-known that many electrical and mechanical faults in induction motors have a direct impact on the motor magnetic field. Indeed, they modulate it [13]. Moreover, it has been proven that failures in a mechanical drive train connected to an induction machine can be detected at the terminal of the machine [14].

In the case of wind turbine condition monitoring, a number of published works are based on the following hypothesis: It is possible to detect wind turbine drive train faults through the terminals of the associated generator [15-16].

The basic configuration that is used for WECS condition monitoring and diagnosis is shown by Fig. 7. It should be noticed that in modern wind turbines, some signals, such as rotational speed, generator temperature, etc., are commonly monitored by the supervisory control system [4].

\section{A. Electrical System (DFIG) Condition Monitoring}

There are many techniques and tools available, which are used to monitor the condition of induction machines. Some of the technology used for monitoring includes sensors, which may measure speed, output torque, vibrations, temperature, flux densities, etc. These sensors are together coupled with algorithms and architectures, which allows for efficient monitoring of the machines condition [17].

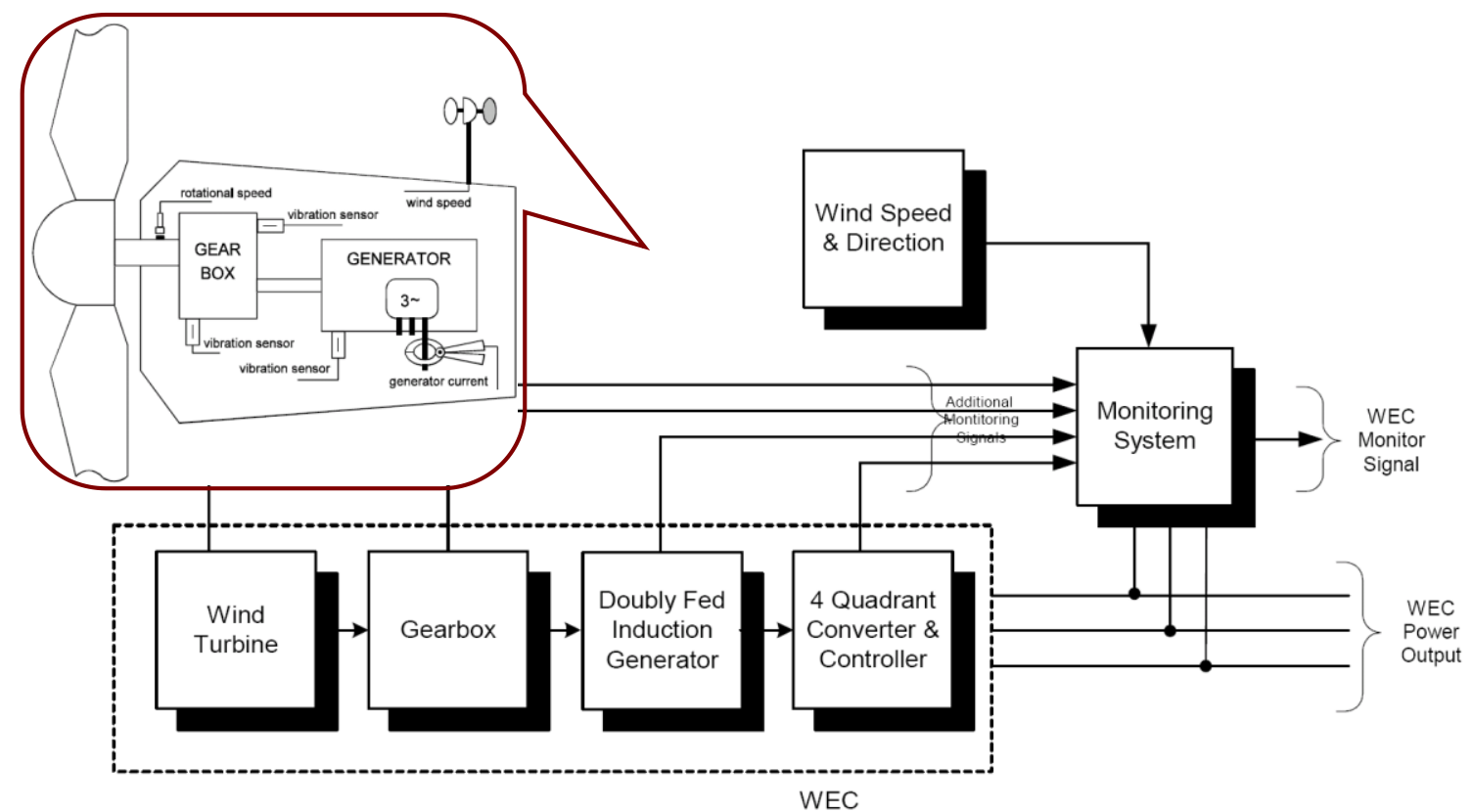

Fig. 7. Basic architecture of WECS condition monitoring and diagnosis [4]. 
The most popular methods of induction machine condition monitoring utilize the steady-state spectral components of the stator quantities. These stator spectral components can include voltage, current, and power and are used to detect turn faults, broken rotor bars, bearing failures and air gap eccentricities [18-19].

The above techniques that are based on steady-state analysis are being applied to induction generators. When scanning the available literature, it has been found that fault detection and diagnosis techniques are mainly arranged for inter-turn stator faults and stator or rotor asymmetries [20-24]. In all these works, authors are just applying wellestablished techniques to induction generators. However, in [20-21], the authors are using the rotor modulating signals spectra as a diagnosis index for stator and rotor fault characterization. Indeed, the rotor modulating signals have harmonic content that gives evidence of stator and rotor asymmetries more clearly than the harmonic content of stator and rotor currents.

In [25], authors have raised a key feature of wind turbine generator operations. Indeed, they are predominantly transient, therefore prompting the use of nonstationary techniques for fault detection [26]. In this case, wavelet analysis has been used for the detection of stator turn faults in a DFIG. The detection algorithm is a combination of the Extended Park Vector, wavelet analysis, and statistics. This technique was not affected by changes in DFIG speed, which is crucial in WECS applications.

One of the preferred options at present, for large turbines in excess of 2-MW rating, is the variable speed DFIG with the rotor converter connected to the rotor via slip rings [7], [27]. However, in contrast to squirrel cage generators there are additional wear parts, e.g. the slip ring system (Fig. 8). Therefore, in [28], the authors are suggesting a patented diagnostic technique for the monitoring of the transmission properties and sparking of DFIG with slip rings. In this case, modifications in the transmission properties are diagnosed using the monitored rotor currents through FFT analysis.

\section{B. Damage Detection of WECS Blades}

Wind turbine blades are a vital component. Due to external conditions and internal stress as well as fatigue, the crack and damage may gradually take place as time goes by, thus leading to performance deterioration of wind generation. In other words, it is crucial to monitor the turbine blades so that operation performance can be better ensured. 


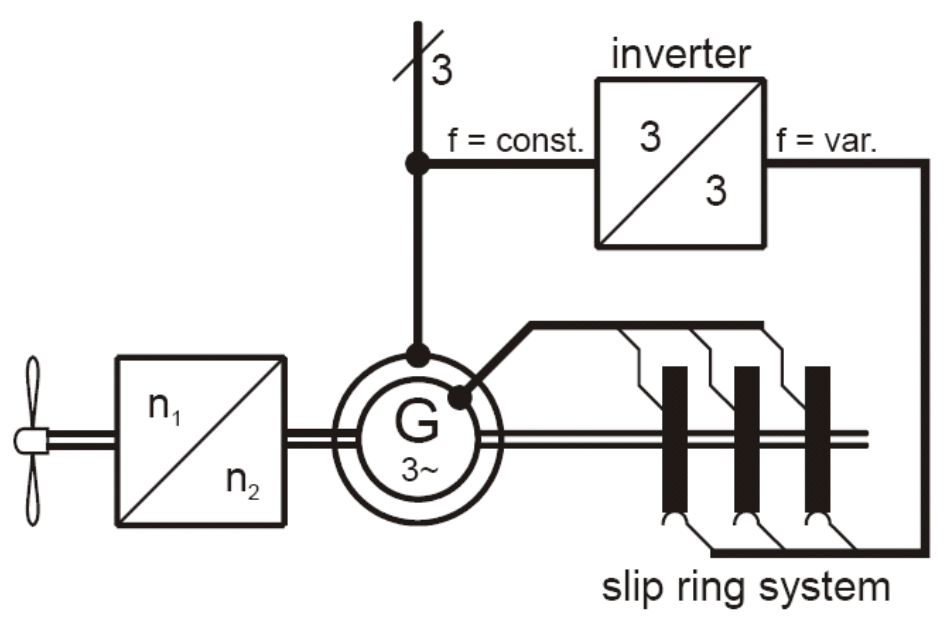

Fig. 8. Slip ring generator system principle.

It should be possible to retrofit a condition monitoring package onto existing wind turbines without requiring additional sensors and wiring on the machine. Therefore, in [29], the authors used the above mentioned hypothesis to detect the presence of unbalance and defects in the blades of a small wind turbine by measuring the power spectrum density at the generator terminals. In this case, bicoherence, a normalized bispectrum, is used. Indeed, it is able to monitor small physical changes in the machine using a very noisy signal. This technique overcomes problems of the bispectrum which is not convenient for detection purposes [19]. The advantage of such an approach is that the generator terminal quantities are easily accessible during operation, the current via a current transformer, the voltage via a voltage transformer and the power by computation. This is a very useful technique as it requires no additional sensors, particularly on the blades, which is the case in [30], where a continuous wavelet transform-based approach is used to detect blade damage.

Unfortunately, wind turbine blades experience faults and damages that could not be monitored using the wind turbine generator terminals. They are particularly exposed to a major threat from lightning strikes. To prevent damage, blades are equipped with a lightning protection system, like most modern WECS [31] (Fig. 9). However, as lightning is random in nature, a complete protection against its damage is not achievable. Therefore in [32], a method for lightning impact localization and classification using a fiber optic current sensor network that helps to detect damages caused by lightning and to monitor the blades is presented. The system is connected to the wind turbine control and monitoring system. 


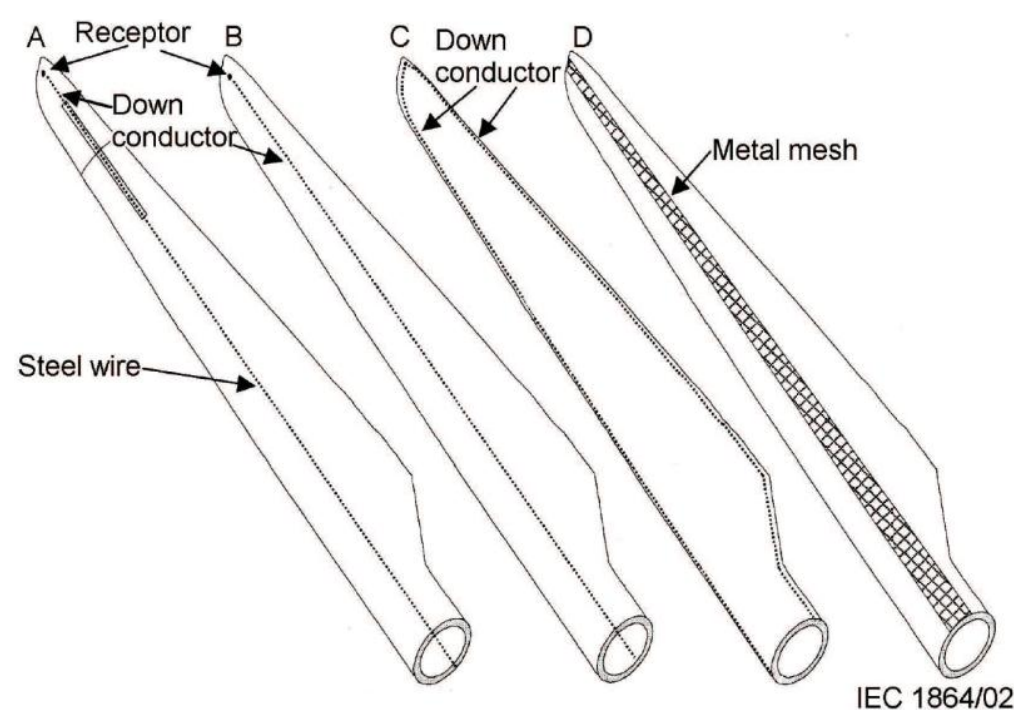

Fig. 9. Lightning protection for large modern wind turbine blades [32].

\section{Other Drive Train Component Monitoring and Diagnosis}

Other wind turbine key components are roller bearings and gears. For these types of component condition monitoring and diagnosis, the use of the wind turbine generator terminals has not been explicitly investigated. Indeed, in [33] the authors dealt with the demodulation of the current signal of an induction motor driving a multistage gearbox for its fault detection. In this case, amplitude demodulation and frequency demodulation are applied to the induction motor current to detect the rotating shaft frequencies. A discrete wavelet transform is applied to the demodulated current signal for denoising and removing the intervening neighboring features. Spectrum of a particular level is used for gear fault detection. This technique seems to be very interesting to monitor WECS gearbox as it involves a nonstationary technique.

In the case of rolling bearing fault diagnosis and apart from the well-established techniques developed for induction motor drives [18], a recently published paper seems to be convenient for wind turbine bearing fault detection [34]. Indeed, it uses the wind turbine generator stator current. Moreover, due to the nonstationary nature of this current, the wavelet packet transform provides better analysis under varying load conditions. The wavelet packet transform also permits the tailoring of the frequency bands to cover the range of bearing fault induced frequencies resulting from rotor speed variations (e.g. variable speed DFIG). 
In [35], the authors propose the application of artificial intelligence techniques for WECS condition monitoring, including the tower, nacelle, and power train. This approach requires a learning process for each individual WECS, and seeks to detect trends, without necessarily linking cause to fault effects. In this case, the proposed approach for WECS monitoring is shown by Fig. 10, where the layer, called evaluation or diagnosis uses neural networks for characteristics learning or fuzzy techniques to combine information from different measurements.

\section{E. Data Collection}

Today, most turbines are fitted with equipment that makes it possible to collect condition monitoring data remotely via modem or internet. Moreover, since wind turbines are typically built in onshore or offshore wind farm configurations, there is a need to build up networks (Fig. 11).

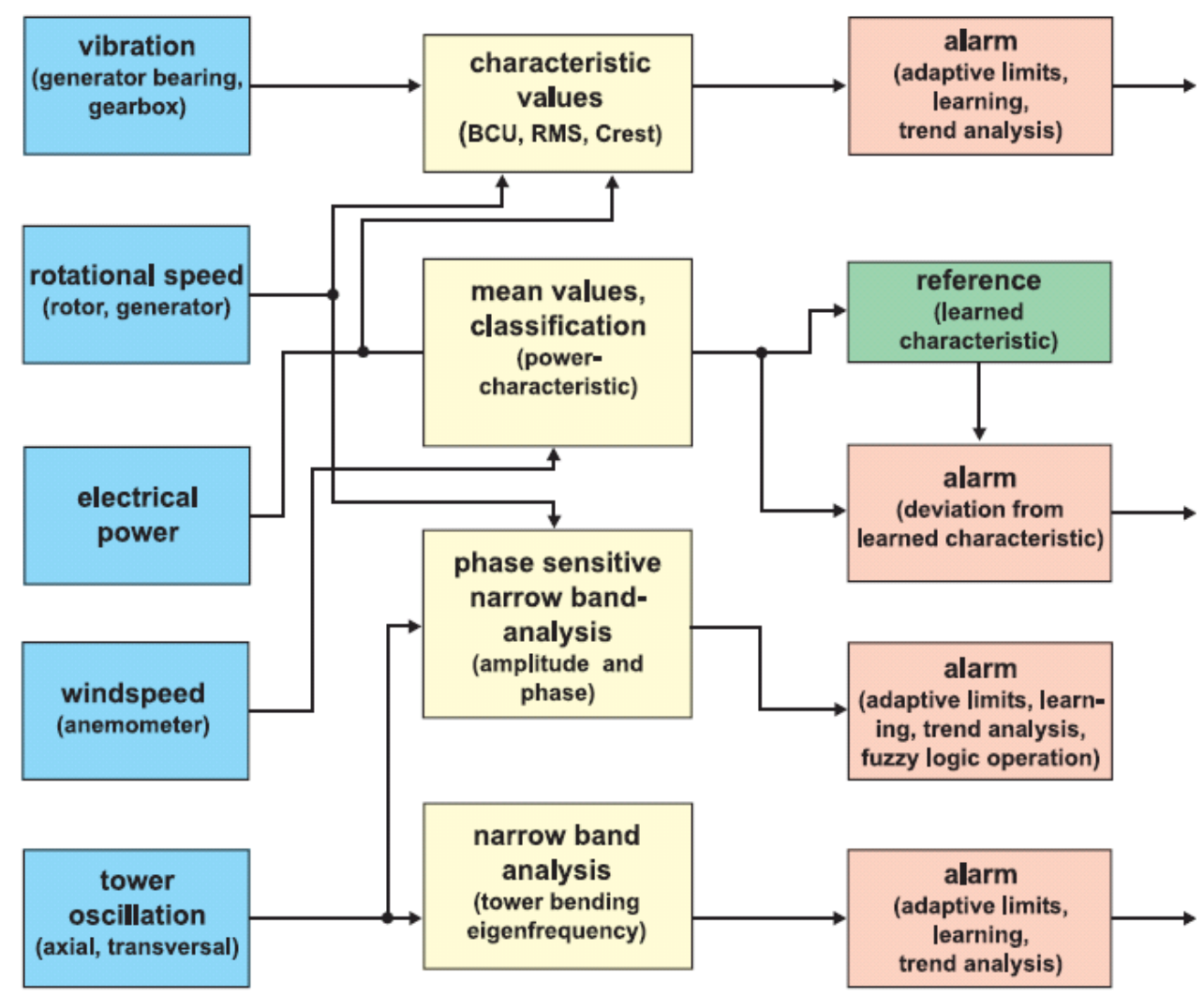

Fig. 10. Bases for WECS condition monitoring and diagnosis [35]. 


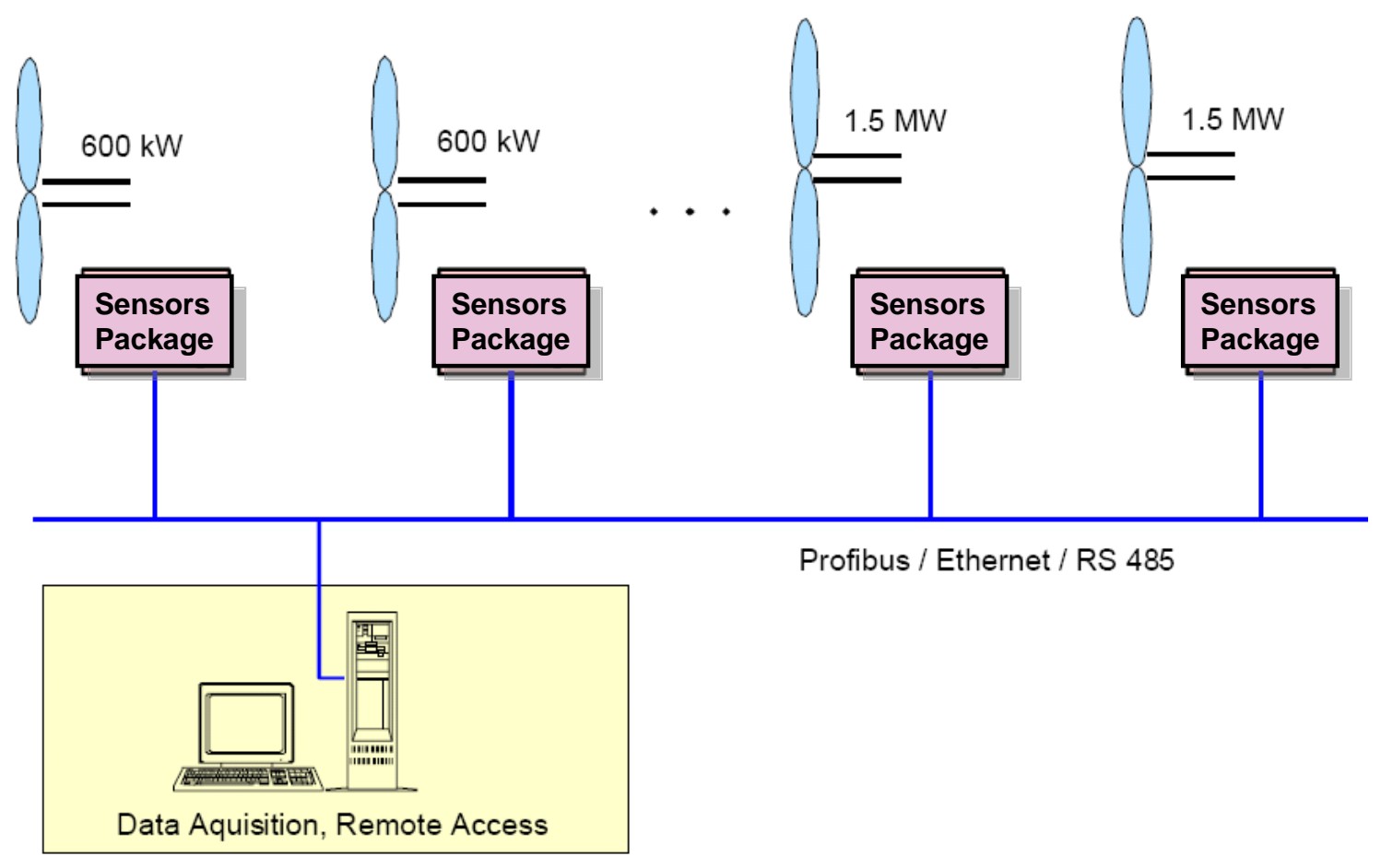

Fig. 11. Condition monitoring network in wind farms.

With this network approach, fault diagnosis will be optimized comparing WECS operation under identical conditions. Moreover, redundant measurements provided by the wind farm (e.g. wind speed) will be used to improve the overall wind farm performance by minimizing operational losses due to anemometer failures [6], [35].

\section{INDUSTRY APPLICATIONS}

Condition monitoring is a machine maintenance tool (known as Condition Monitoring System - CMS) that is becoming a component of long-term service packages provided by some wind turbine manufacturers. Figure 12 illustrates the integration of a CMS in a WECS [36-37]. In this case, the CMS monitoring functions are based on robust sensor equipment. A typical sensor configuration is shown by Fig. 13: Sensor (1) is an inductive distance sensor to measure the absolute rotor position; Sensors (2), (3) and (4) are static accelerometers to measure the nacelle oscillation in axial and transverse direction, related to the rotor axis; Sensors (5) and (6) are vibration sensors to measure the vibration induced by bearings and gearwheels. 


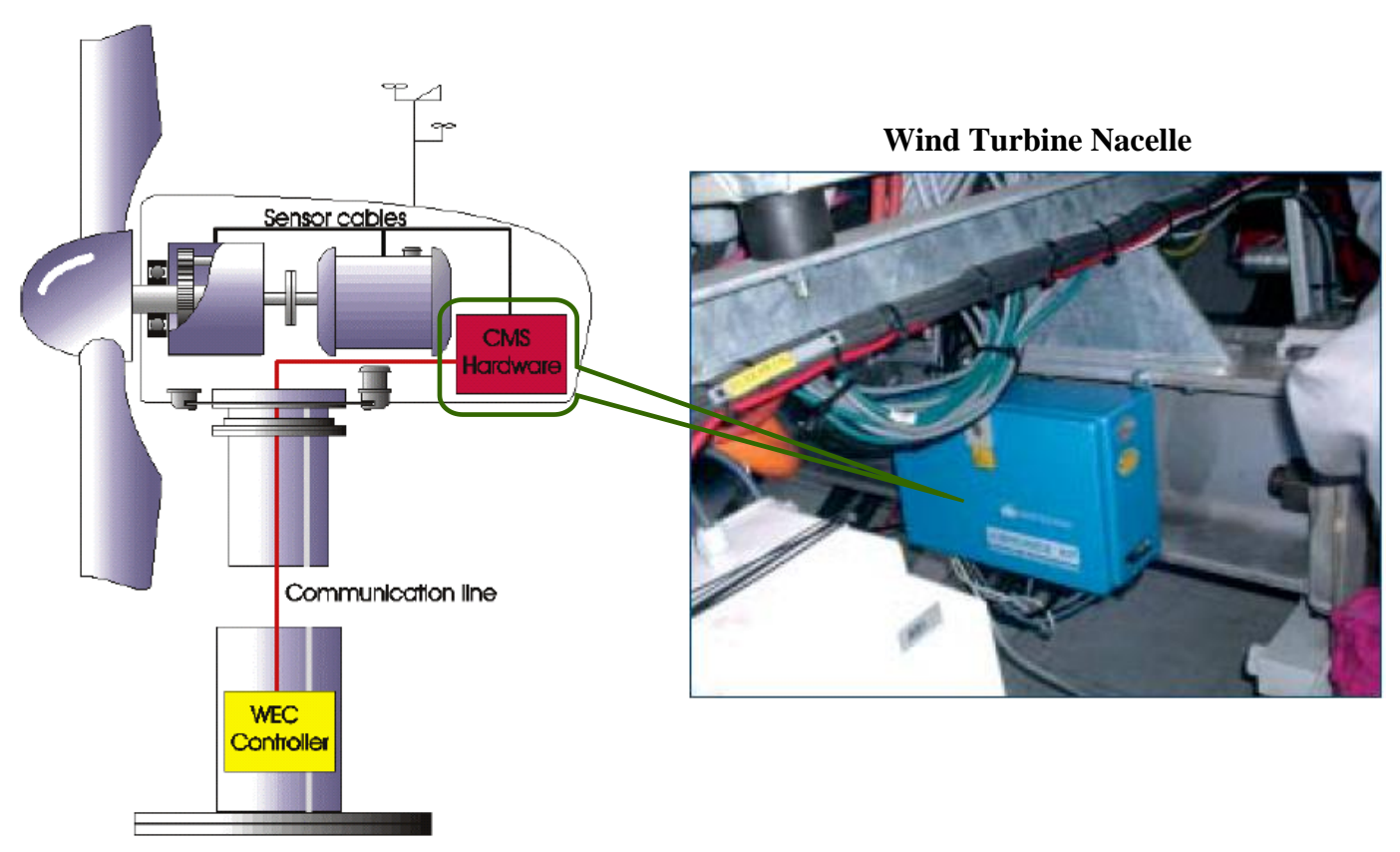

Fig. 12. Integration of a CMS in a WECS [36].

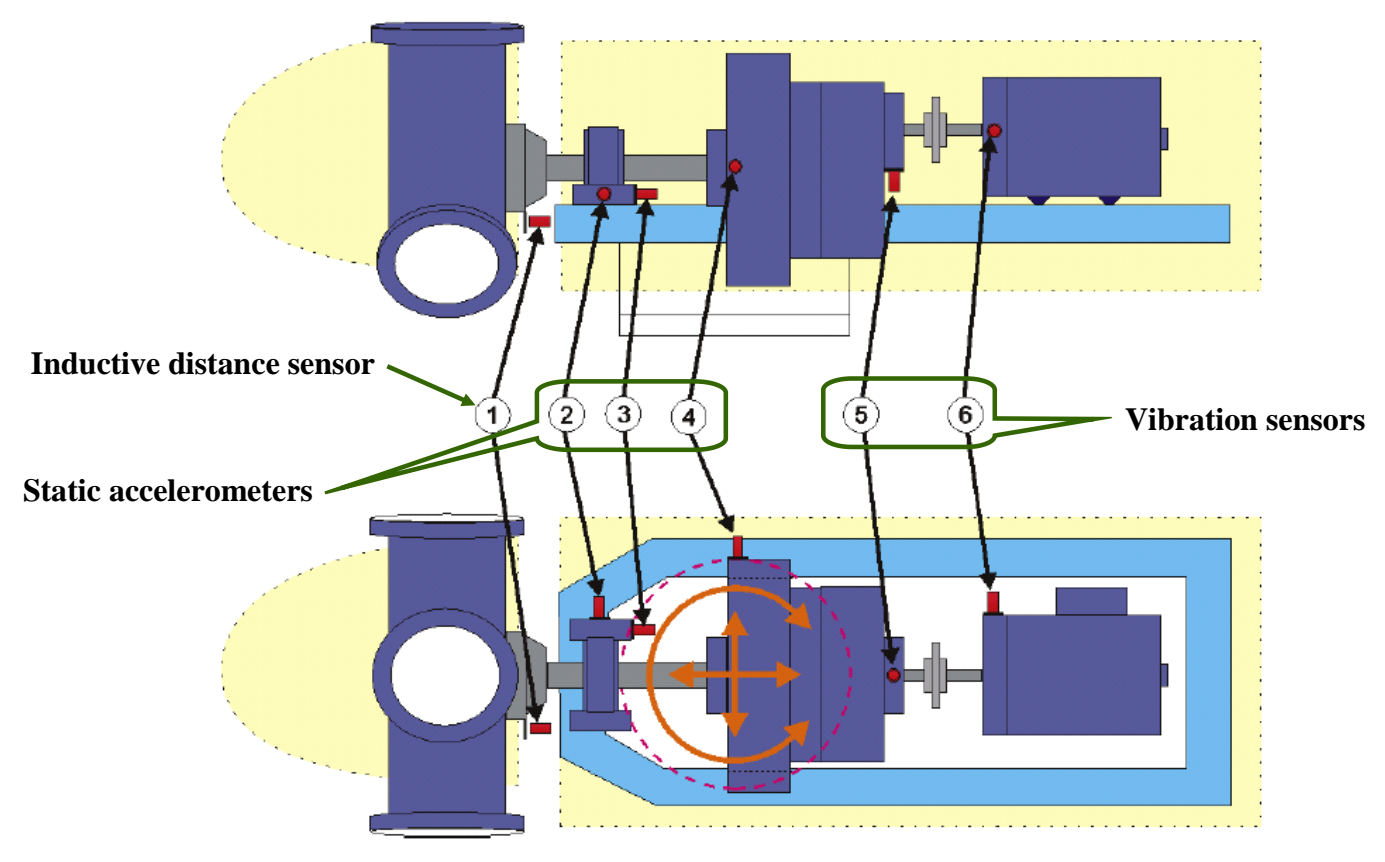

Fig. 13. Typical sensor position [36].

\section{V.SUMMARY}

This paper has briefly reviewed state of art of wind energy conversion systems condition monitoring and diagnosis. The emphasis has been put on faults that could be 
monitored using wind turbine generator (DFIG) terminals in an attempt to use wellestablished techniques developed for induction motors. Indeed, it seems that it is possible to detect wind turbine drive train faults through the terminals of the associated generator. In this context, it has been found that unbalance and defects in small wind turbine blades can be diagnosed by measuring the power spectrum density at the generator terminals. This was also the case of WECS gearbox. However, as wind turbine generator operations are predominantly transient, the use of nonstationary techniques is required for fault detection.

Finally industry application of condition monitoring has been briefly introduced through CMS.

\section{REFERENCES}

[1] R. Thresher et al., "The status and future of wind energy technology," IEEE Power \& Energy Magazine, vol. 5, no. 6, pp. 34-46, November/December 2007.

[2] M.E.H. Benbouzid et al., "Condition monitoring and fault diagnosis in wind energy conversion systems," in Proceedings of IEEE IEMDC'07, pp. 1434-1439, Antalya (Turkey), May 2007.

[3] P. Caselitz et al., "On-line fault detection and prediction in wind energy converters," in Proceedings of EWEC'94, pp. 623-627, Thessaloniki (Greece), 1994.

[4] P. Caselitz et al., "Development of a fault detection system for wind energy converters," in Proceedings of EUWEC'96, pp. 1004-1007, Göteborg (Sweden), 1996.

[5] P. Caselitz et al., "Application of condition monitoring systems in wind energy converters," in Proceedings of EWEC'97, pp. 579-582, Dublin (Ireland), 1997.

[6] J. Nilsson et al., "Maintenance management of wind power systems using condition monitoring systems - Life cycle cost analysis for two case studies," IEEE Trans. Energy Conversion, vol. 22, n¹, pp. 223-229, March 2007.

[7] M.E.H. Benbouzid et al., "The state of the art of generators for wind energy conversion systems," in Proceedings of ICEM'06, Chania (Greece), September 2006. 
[8] J. Ribrant et al., "Survey of failures in wind power systems with focus on Swedish wind power plant during 1997-2005," IEEE Trans. Energy Conversion, vol. 22, n¹, pp. 167-173, March 2007.

[9] J. Ribrant, Reliability performance and Maintenance - A Survey of Failure in Wind Power Systems, Master Thesis, KTH School of Electrical Engineering, 2006.

[10] P.J. Tavner et al., "Reliability analysis for wind turbines," Journal of Wind Energy, vol. 10, n¹, pp. 1-18, March-April 2006.

[11] P. J. Tavner et al., "Machine and converter reliabilities in wind turbines," in Proceedings of IEE PEMD'06, Dublin (Ireland), 2006.

[12] M. Mohsin Khan et al., "Reliability and condition monitoring of a wind turbine," in Proceedings of IEEE CCECE'05, Saskatoon (Canada), 2005.

[13] S. Nandi et al., "Condition monitoring and fault diagnosis of electrical motors - A review," IEEE Trans. Energy Conversion, vol. 20, n4, pp. 719-729, December 2005.

[14] R. Yacamini et al., "Monitoring torsional vibrations of electromechanical systems using stator currents," ASME Journal of Vibration \& Acoustics, vol. 120, pp. 72-79, 1998.

[15] M.R. Wilkinson et al., "Extracting condition monitoring information from a wind turbine drive train," in Proceedings of UPEC'04, vol. 1, pp. 591-594, Bristol (UK), 2004.

[16] M.R. Wilkinson et al., "Condition monitoring of wind turbine drive trains," in Proceedings of ICEM'06, Chania (Greece), September 2006.

[17] M.E.H. Benbouzid, "Bibliography on induction motors faults detection and diagnosis," IEEE Trans. Energy Conversion, vol. 14, n4, pp. 1065-1074, December 1999.

[18] M.E.H. Benbouzid et al., "What stator current processing based technique to use for induction motor rotor faults diagnosis?," IEEE Trans. Energy Conversion, vol. 18, n², pp. 238-244, June 2003.

[19] M.E.H. Benbouzid, "A review of induction motors signature analysis as a medium for faults detection," IEEE Trans. Industrial Electronics, vol. 47, n5, pp. 984-993, October 2000.

[20] D. Casadei et al., "Diagnostic technique based on rotor modulating signals signature analysis for doubly fed induction machines in wind generator systems," 
in Proceedings of IEEE IAS'06, vol. 3, pp. 1525-1532, Tampa (USA), October 2006.

[21] D. Casadei et al., "Experimental fault characterization of doubly fed induction machines for wind power generation," in Proceedings of IEEE SPEEDAM'06, pp. 1281-1286, Taormina (Italy), May 2006.

[22] I. Albizu et al., "On-line stator winding fault diagnosis in induction generators for renewable generation," in Proceedings of IEEE MELECON'04, vol. 3, pp. 10171020, Dubrovnik (Croatia), May 2004.

[23] Q.F. Lu et al., "Model of stator inter-turn short circuit fault in doubly-fed induction generators for wind turbine," in Proceedings of IEEE PESC'04, vol. 2, pp. 932-937, Aachen (Germany), June 2004.

[24] L. Mihet-Popa et al., "Condition monitoring of wind generators," in Proceedings of IEEE IAS'03, vol. 3, pp 1839-1846, Salt Lake City (USA), October 2003.

[25] H. Douglas et al., "The detection of interturn stator faults in doubly-fed induction generators," in Proceedings of IEEE IAS'05, vol. 2, pp. 1079-1102, Honk Kong, October 2005.

[26] K. Kim et al., "Induction motor fault diagnosis based on neuropredictors and wavelet signal processing," IEEE/ASME Trans. Mechatronics, vol. 7, n², pp. 201219, June 2002.

[27] R. Datta et al., "Variable-speed wind power generation using doubly fed wound rotor induction machine-A comparison with alternative schemes," IEEE Trans. Energy Conversion, vol. 17, n³, pp. 414-421, September 2002.

[28] M. Würfel et al., "monitoring of the properties of the rotor slip ring system of doubly-fed induction generators," in Proceedings of IEEE IEMDC'05, pp. 295-299, San Antonio (USA), May 2005.

[29] W.Q. Jeffries et al., "Experience with bicoherence of electrical power for condition monitoring of wind turbine blades," IEE Proc. Vision, Image and Signal processing, vol. 145, n³, pp. 141-148, June 1998.

[30] C.S. Tsai et al., "Enhancement of damage-detection of wind turbine blades via CWT-based approaches," IEEE Trans. Energy Conversion, vol. 21, n³, pp. 776781, September 2006.

[31] I. Cotton et al., "Lightning protection for wind turbine blades and bearings," Wind Energy, pp. 23-37, 2001. 
[32] S.G.M. Krämer et al., "Fiber optic sensor network for lightning impact localization and classification in wind turbines," in Proceedings of IEEE ICMFIIS'06, vol. 2, pp. 173-178, Heidelberg (Germany), September 2006.

[33] A.R. Mohanty et al., "Fault detection in a multistage gearbox by demodulation of motor current waveform," IEEE Trans. Industrial Electronics, vol. 53, n4, pp. 1285-1297, August 2006.

[34] L. Eren et al., "Bearing damage detection via wavelet packet decomposition of the stator current," IEEE Trans. Instrumentation \& Measurement, vol. 53, n², pp. 431-436, April 2004.

[35] P. Caselitz et al., "Advanced condition monitoring system for wind energy converter," in Proceedings of EWEC'02, Nice (France), 2002.

[36] European Commission / DG TREN, "Advanced maintenance and repair for offshore wind farms using fault prediction and condition monitoring techniques," Final Report, NNE5/2001/710, FP5 Contract, 2005.

[37] P. Caselitz et al., "Rotor condition monitoring for improved operational safety of offshore wind energy converters," Journal of Solar Energy Engineering, vol. 127, $\mathrm{n}^{\circ} 2$, pp. 253-261, May 2005.

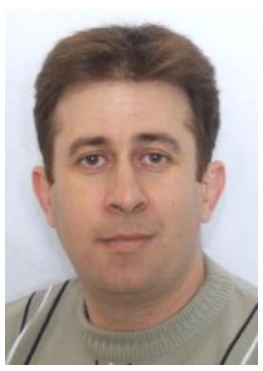

Yacine Amirat was born in Annaba, Algeria, in 1970. He received the B.Sc. and M.Sc. degrees both in Electrical Engineering, from the University of Annaba, Algeria, in 1994 and 1997 respectively.

He is currently pursuing Ph.D. studies on wind power control. His main research interests include analysis, design, and control of electric machines, and renewable energies.

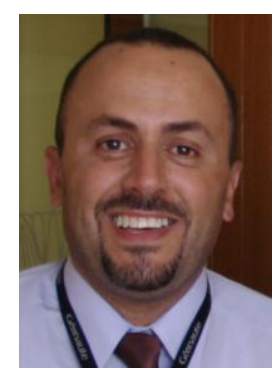

Mohamed El Hachemi Benbouzid (S'92-M'95-SM'98) was born in Batna, Algeria, in 1968. He received the B.Sc. degree in electrical engineering from the University of Batna, Batna, Algeria, in 1990, the M.Sc. and Ph.D. degrees in electrical and computer engineering from the National Polytechnic Institute of Grenoble, Grenoble, France, in 1991 and 1994, respectively, and the Habilitation à Diriger des Recherches degree from the University of Picardie "Jules Verne," Amiens, France, in 2000.

After receiving the Ph.D. degree, he joined the Professional Institute of Amiens, University of Picardie "Jules Verne," where he was an Associate Professor of electrical 
and computer engineering. In September 2004, he joined the University Institute of Technology (IUT) of Brest, University of Brest, Brest, France, as a Professor of electrical engineering. His main research interests and experience include analysis, design, and control of electric machines, variable-speed drives for traction and propulsion applications, and fault diagnosis of electric machines.

Prof. Benbouzid is a Senior Member of the IEEE Power Engineering, Industrial Electronics, Industry Applications, Power Electronics, and Vehicular Technology Societies. He is an Associate Editor of the IEEE TRANSACTIONS ON ENERGY Conversion, the IEEE TRANSACTIONS ON Industrial Electronics, the IEEE Transactions on Vehicular Technology, and the IEEE/ASME Transactions on MECHATRONICS.

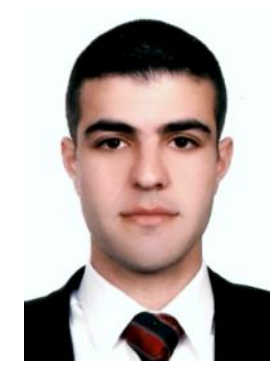

Elie Al Ahmar was born in Bsarma Al Koura, Lebanon, in 1982. He received the B.Sc degree in Computer and Communication Engineering in 2006 from the Holy Spirit University of Kaslik, Lebanon. He is a Research Assistant at the Faculty of Sciences and Computer Engineering, Holy Spirit University of Kaslik.

He is currently pursuing Ph.D. studies on wind turbine monitoring and diagnosis.

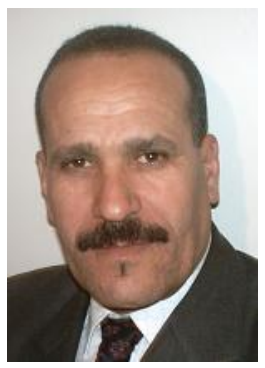

Bachir Bensaker was born in was born in Roknia, Algeria, in 1954. He received the B.Sc. degree in Electronics Engineering from the University of Science and Technology of Oran, Oran, Algeria, in 1979. From 1979 to 1983, he was a Teaching Assistant with the Department of Electronics Engineering, University of Annaba, Annaba, Algeria. He received the M.Sc. degree and the Ph.D. degree in Instrumentation and Control from the University of Le Havre, Le Havre, France, in 1985 and 1988 respectively. Since 1988, he has been with the Department Electronics Engineering, University of Annaba, Annaba, Algeria, where, since 2004, he has been a Professor. From 1990 to 1998, he has been an Associate Professor with the Industrial Engineering Education Centre (CIFI).

Since 1991, he has been an IFAC Affiliate. His current research interests are focused on nonlinear modeling, condition monitoring, fault detection and diagnostics of electrical machines. 


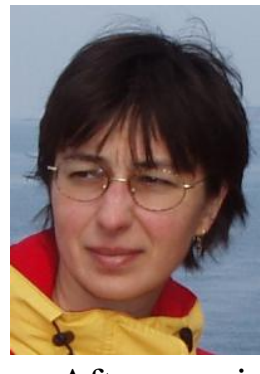

Sylvie Turri was born in France, in 1972. She received the M.Sc. degree in electrical engineering from the University of Nancy, Nancy, France, in 1996. She was awarded the Ph.D. degree in electrical engineering from the University of Franche-Comté, Belfort, France in 2000.

After receiving the Ph.D. degree, she joined the Ecole Nationale Supérieure of Cachan and the SATIE Lab (UMR CNRS 8029) at Rennes, France, as a Teaching and Research Associate. In 2004, she joined the University Institute of Technology (IUT) of Aix-Marseille, University of Marseille III, Marseille, France, as an Associate Professor of electrical engineering. She was appointed to the LSIS Lab (UMR CNRS 6168). In 2006, she joined the University Institute of Technology (IUT) of Brest, University of Western Brittany, Brest, France, as an Associate Professor of electrical engineering. Her main research interests are in the field of electromechanical systems (power generation, fault diagnosis). 